\title{
Mapping of the Pneumococcus Chromosome. Linkage between the Genes Conferring Resistances to Erythromycin and Tetracycline and Its Implication to the Replication of the Chromosome
}

\author{
By L. O. BUTLER AND G. NICHOLAS \\ Department of Medical Microbiology, St George's Hospital Medical School. \\ Hyde Park Corner, London, S.W.I
}

(Received 4 July 1972; revised 7 June 1973)

\begin{abstract}
SUMMARY
In the process of constructing a map of the pneumococcus chromosome by transformation, a search for linkage groups involving the markers ery-r2, str-r4I, amiA-rI, opt-r2 and tet- $A$ has been carried out. No linkage was found amongst the first four markers, but linkage was found between ery-r2 and tet- $A$. The discrepancy between these results and the previously reported linkage between the loci conferring resistance to erythromycin and streptomycin is discussed. The anomalous position of the ery-r2-tet-A linkage in relation to the chromosome map obtained by the density-shift method, and the implications to the mode of replication of the chromosome, are discussed. Two models are proposed for the replication of the pneumococcal chromosome.
\end{abstract}

\section{INTRODUCTION}

A previous paper (Butler \& Smiley, I973) reported a beginning to the construction of a map of the pneumococcus chromosome by the density-shift method. To support and enlarge such a map, a search for linkage groups was carried out. Linkage between genes in bacterial transformation is taken to mean that the two genes concerned can be situated on the same piece of transforming deoxyribonucleic acid (DNA). Unlinked genes are therefore those which never occur on the same molecule of DNA, and double transformants obtained possessing such genes must be derived by the integration of two separate molecules of DNA resulting from independent events. In pneumococcus, the only definitive evidence for linkage groups concerns the gene conferring streptomycin resistance which is linked both to the mannose utilization gene and to loci conferring sulphanilamide resistance (Hotchkiss \& Marmur, 1954). There are also reports by Ravin and his collaborators (Ravin, I966; Ravin \& Chen, 1967) that streptomycin and erythromycin are linked. The lack of linkage between the pairs streptomycin and optochin, aminopterin and optochin and streptomycin and bryamycin has been inferred by Rolfe \& Ephrussi-Taylor (196I) in the course of density gradient experiments, and support for these conclusions has been given by Martin \& Ephrussi-Taylor (1964) and by Louarn \& Sicard (1969).

Except for the work of Ravin, no direct genetic evidence concerning the antibiotic resistance markers is available, and the work to be reported is designed to provide such evidence. The criteria used for linkage have been (i) the appearance of dilution curves; (ii) the frequencies of double transformants; and (iii) the co-transfer index of Nester \& Lederberg (I96I). In (i), double events giving rise to double transformants to unlinked genes will become rarer as the DNA concentration is reduced and hence the numbers of 


\section{Table I. Description of the pneumococcal strains used}

\begin{tabular}{|c|c|c|}
\hline Strain & Genotype & Comments \\
\hline \multicolumn{3}{|l|}{ Recipients } \\
\hline $\mathrm{Cl}_{3}$ & Wild-type & Isolated by Ephrussi-Taylor (I95I) \\
\hline AmI & $a m i A-r I$ & Derived from strain $\mathrm{Cl}_{3}$ (Sicard, I964) \\
\hline \multicolumn{3}{|l|}{ Donors } \\
\hline $\mathrm{Cl}_{3}-\mathrm{S}$ & str-r $4 I$ & \\
\hline $\mathrm{Cl} 3-\mathrm{r}_{2}$ & ery-r2 & Derived from cross $\mathrm{Cl}_{3} \times\left(\mathrm{r}_{2} \mathrm{SQ}\right)$ \\
\hline $\mathrm{Cl} 3-\mathrm{Q}$ & opt-r2 & \\
\hline $\mathrm{Cl}_{3}-\mathrm{TC}_{3}$ & tet $-A$ & $\begin{array}{l}\text { Derived from strain } \mathrm{Cl}_{3} \text { by transformation } \\
\text { with DNA from strain } \mathrm{Tc}_{3} \text { derived from } \\
\text { NNG mutagenesis of strain cl3 } \\
\text { (Butler \& Smiley, I970, I973) }\end{array}$ \\
\hline $\mathrm{r}_{2} \mathrm{SQ}$ & $e r y-r 2$ str-r4r opt-r2 & Derived from strain $\mathrm{cl}_{3}$ by transformation \\
\hline $\mathrm{AmIr}_{2} \mathrm{SQ}$ & amiA-rI ery-r2 str-r4I opt-r2 & Derived from cross $\mathrm{AmI} \times\left(\mathrm{r}_{2} \mathrm{SQ}\right)$ \\
\hline $\mathrm{TC}_{3} \mathrm{r}_{2} \mathrm{Q}$ & tet $-A$ ery-r2 opt-r2 & $\left\{\begin{array}{l}\mathrm{Cl}_{3}-\mathrm{Tc}_{3} \times\left(\mathrm{Cl}_{3}-\mathrm{Q}\right) \\
\mathrm{Tc} 3 \mathrm{Q} \times\left(\mathrm{C}_{3}-\mathrm{r}_{2}\right)\end{array}\right.$ \\
\hline $\mathrm{Tc}_{3} \mathrm{r}_{2} \mathrm{~S}$ & tet- $A$ ery'- $r_{2}$ str-r4I & $\left\{\begin{array}{l}\mathrm{Cl}_{3}-\mathrm{Tc} 3 \times\left(\mathrm{Cl}_{3}-\mathrm{s}\right) \\
\mathrm{Tc} 3 \mathrm{~S} \times\left(\mathrm{Cl}_{3}-\mathrm{r}_{2}\right)\end{array}\right.$ \\
\hline $\mathrm{Tc}_{3} \mathrm{r}_{2} \mathrm{SQ}$ & tet $-A$ ery-r2 str-r4I opt-r2 & $\mathrm{Tc}_{3} \mathrm{r}_{2} \mathrm{Q} \times\left(\mathrm{Cl}_{3}-\mathrm{s}\right)$ \\
\hline $\mathrm{Tc}_{3} \mathrm{AmIr} \mathrm{Ir}_{2} \mathrm{SQ}$ & tet $-A$ amiA-rI ery-r2 str-r4I opt-r2 & $\left(\mathrm{AmIr} \mathrm{r}_{2} \mathrm{SQ} \times\left(\mathrm{Tc}_{3} \mathrm{r}_{2} \mathrm{Q}\right)\right.$ \\
\hline
\end{tabular}

such transformants will fall off more steeply than those due to linked genes. Criterion (ii) is permissible in pneumococcal transformation since the numbers of competent organisms in a competent culture are high (Fox \& Hotchkiss, 1957; Nester \& Stocker, I963; Porter \& Guild, 1969), and it does not give rise to the spurious linkage observed by Anagnostopoulos \& Crawford (I96I) for transformation in Bacillus subtilis due to comparatively low numbers of competent cells in a competent culture of $B$. subtilis (Cahn \& Fox, I968; Nester \& Stocker, I963).

\section{MATERIALS}

Organisms. The wild-type strain used was the transformable strain of Diplococcus pneumoniae known as Clone $3\left(\mathrm{Cl}_{3}\right)$ derived from the strain R36A of Avery, MacLeod \& McCarty (I944) by Ephrussi-Taylor (I95I). All other strains used were derived from $\mathrm{Cl}_{3}$ and are listed in Table I. Stock cultures were maintained as previously described (Butler, I965; Butler \& Smiley, 1970).

Media. The peptone media ' $\mathrm{P}$ ' and 'NS' were prepared as previously described (Sicard, 1964; Butler, 1965).

Preparation of DNA. Two methods of preparation of the donor DNA were used: Method I. This method has been described by Butler \& Smiley (1970), and was based on Sicard (1965) and Martin \& Ephrussi-Taylor (1964). Deproteinization was by the Sevag method (Sevag, Lackman \& Smolens, 1938). Method II. A forced culture of the pneumococci was prepared in the same way as for method I. The extraction of this culture was then carried out by modification of the methods of Berns \& Thomas (1965), Kirby (1965), and Bacon, Overend, Lloyd \& Peacocke (I967). The culture (I500 ml) was centrifuged and resuspended in $\mathrm{I}_{50} \mathrm{ml}$

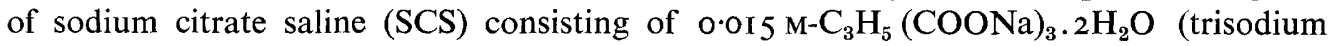
citrate) and $0.15 \mathrm{M}-\mathrm{NaCl}$. At this point, it was often stored overnight at $4{ }^{\circ} \mathrm{C}$. Fifteen $\mathrm{ml}$ of $20 \%(\mathrm{w} / \mathrm{v})$ sodium dodecyl sulphate in SCS were added, giving a final concentration of $2 \%$ sodium dodecyl sulphate, and incubated at $37{ }^{\circ} \mathrm{C}$ for $45 \mathrm{~min}$. Pronase (Type VI, Sigma 
Chemical Company, St Louis, U.S.A.) was then added to give a final concentration of I $\mathrm{mg} / \mathrm{ml}$, and incubated at $37^{\circ} \mathrm{C}$ for $2 \mathrm{~h}$. An equal volume of a mixture consisting of $250 \mathrm{ml}$ $90 \%$ phenol in water, $35 \mathrm{ml} \mathrm{m}$-cresol, and $2.5 \mathrm{~g} 8$-hydroxyquinoline, was added and mixed gently for $20 \mathrm{~min}$ at room temperature. After centrifuging at $2500 \mathrm{rev}$. $/ \mathrm{min}$ for $20 \mathrm{~min}$, the DNA-containing layer was carefully taken off with a wide-bore pipette and $\mathrm{NaCl}$ added to a final concentration of $3 \%(\mathrm{w} / \mathrm{v})$. The phenol extraction was repeated with $0.5 \mathrm{vol}$. of the phenol mixture. The precipitate from the first phenol extraction was further extracted with SCS overnight and given the second phenol extraction. The phenol was removed from the DNA solution by washing twice with diethyl ether, and the ether removed by evaporation under reduced pressure. An equal volume of ethyl alcohol was added and the DNA spooled, redissolved in SCS and re-spooled on the addition of a volume of ethyl alcohol. The DNA was then finally dissolved in sterile $0.15 \mathrm{M}-\mathrm{NaCl}$.

Assay of transforming activity. The method used was essentially as described previously (Butler, I965), except that $\mathrm{I} \cdot 0 \mathrm{ml}$ of the competent culture was added to $0.1 \mathrm{ml}$ of suitable dilutions of the DNA solutions. Double transformants were assayed by the addition of a top layer of nutrient agar containing the two antibiotics after full expression had been allowed for the gene having the longest expression time. The same concentrations of antibiotics were used for doubles as for single transformants.

Assay of colony-forming units. A portion of the competent culture was taken and suitable dilutions were plated in triplicate in nutrient agar containing horse blood. After overnight incubation the colonies were counted. No correction was made for chain lengths. The object was to relate the number of transformant colonies to the cell number, and since a transformant colony is derived from either a single transformant or from several transformants present in a chain, it seemed appropriate to relate these to the total colony-forming units (c.f.u.) rather than to a viable count which has been corrected for chain lengths. This reasoning holds when assessing the relative frequencies of single transformants but, on reflection, would give spurious results when applied to the assessment of frequencies of double transformants. Either cell of a chain of, for example, two cells would give rise to a singly marked transformant colony, but either one or the other of the cells must receive both the two hits necessary to produce the transformant colony doubly marked to two unlinked markers. Hence, although in the former case the second cell in the chain could have been disregarded, it should not be ignored when calculating frequencies in the latter case. From many observations of chain lengths carried out on similar strains under the same cultural conditions, the average chain length would not be expected to be greater than two (and might even be lower); hence all frequency calculations have been made using the c.f.u. count multiplied by two.

\section{RESULTS}

Experiments were carried out using strains $\mathrm{Cl}_{3}$ and $\mathrm{AmI}$ as recipients, and DNA prepared by method I from the strains as listed in Table $\mathrm{r}$. Either full dilution curves were made, or else a saturating and non-saturating concentration of the donor DNA were used for the production of transformants. Platings were made in triplicate for all single transformants and also for all the possible combinations of double transformants. At the same time, a count of the c.f.u. in the recipient culture was carried out. The dilution curves were plotted, and the frequencies of transformation for each transformant class were determined. The frequencies for the double transformants were compared to the calculated frequencies expected as the maxima for unlinked systems, derived by multiplying together the frequencies of the two 
single events. It is convenient to make this comparison by calculating the linkage index (1.i.):

$$
\text { Linkage index }=\frac{\text { Calculated frequency }}{\text { Experimental frequency }} \text {. }
$$

The linkage index provides a useful assessment of the degree of linkage. If the ideal case of non-linkage occurred when the experimental frequency equalled the calculated frequency, the linkage index would equal $\mathrm{r} \cdot 0$; however, it is more usual for unknown factors to appear, giving rise to non-ideal cases (Porter \& Guild, 1969), when an 1.i. greater than I 0 would occur. Linked systems would have an 1.i. of less than $\mathrm{I} \cdot 0$.

In some cases, the co-transfer indices (CoI) of Nester \& Lederberg were calculated. This index was defined by Nester \& Lederberg (196I) as

$$
\text { Co-transfer index }=\frac{A_{1} B_{1}}{A_{1}+B_{1}-A_{1} B_{1}}
$$

where $A_{1}$ and $B_{1}$ are the number of single transformants to genes $A$ and $B$ respectively, and $A_{1} B_{1}$ is the number of double transformants. Complete linkage would give an index equal tor $\mathrm{O}$.

It is convenient to describe the results in two groups, those not involving and those in volving the tet- $A$ marker.

Experiments not involving the tet-A marker. The linkage indices and the co-transfer indices of double transformants of combinations of the str-r4I, ery-r2, opt-r2 and amiA-rI markers, at saturating and non-saturating concentrations of DNA, are given in Table 2. Both strains $\mathrm{Cl} 3$ and AmI were used as recipients, with a preparation of donor DNA from strain $\mathrm{r}_{2} \mathrm{SQ}$ and two preparations of DNA from strain $\mathrm{AmI}_{2} \mathrm{SQ}$. In each case, the frequency of transformation obtained experimentally was always lower than the calculated frequency, indicated by the linkage index having values greater than $\mathrm{I}$ and by the co-transfer index values being very low, so that there was no evidence of linkage (or co-transfer) between any of the markers. Fig. I is representative of the dilution curves obtained, showing that the numbers of double transformants fell off with dilution of the DNA at a faster rate than the number of single transformants.

Dilution curves were also made with mixtures of DNA preparations where one marker was on one DNA preparation and the other marker on the other DNA preparation, so that co-transfer would be impossible. The values of the linkage index and the co-transfer index for the double transformants str-r4I ery-r2, str-r4I opt-r2, and amiA-rI str-r4I are given in Table 3. These values are of the same order as those given in Table 2, particularly for the str-r4I ery-r2 double, confirming that they behave as unlinked markers.

Experiments involving the tet-A marker. The values of the linkage index and co-transfer index at the varying concentrations of DNA throughout a dilution curve for transformants involving the pairs of markers tet-A str-r4I, tet-A amiA-rI, tet-A ery-r2 and tet-A opt-r2 are given in Table 4. In the two former cases the experimental frequencies were all lower than the calculated frequencies whilst the tet-A ery-r2 double clearly showed linkage. Preparations of DNA from two different (but allied) strains gave evidence of co-transfer. The values of the linkage index for the tet-A opt-r2 double are interesting, since they show a change from weak linkage at the higher DNA concentration to non-linkage at the lower concentrations except for the very lowest concentration, although the values of the co-transfer index all indicated non-linkage. The meaning of this behaviour is not clear. Fig. 2 gives typical dilution curves and it can be seen that the curve for tet-A ery-r2 double transformants follows the slope of the curves for the tet-A, the ery-r2 and the opt-r2 single transformants, whilst the tet-A opt-r2 double transformant fell away rapidly as the DNA was diluted, the 


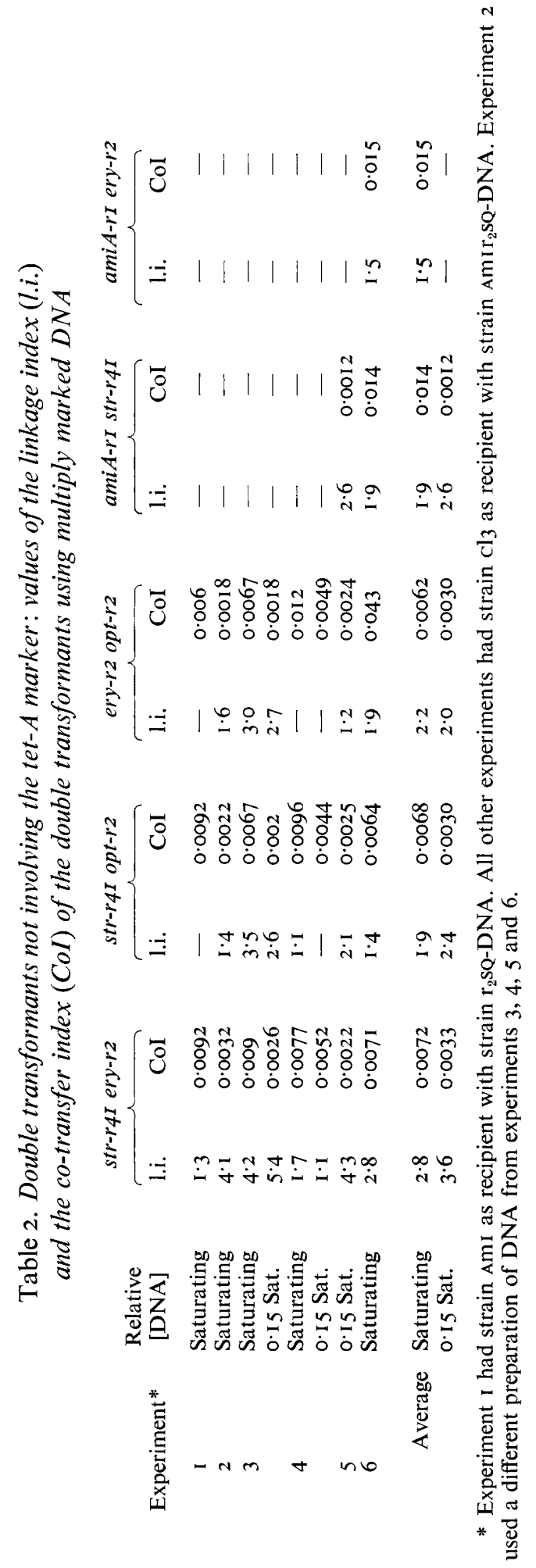




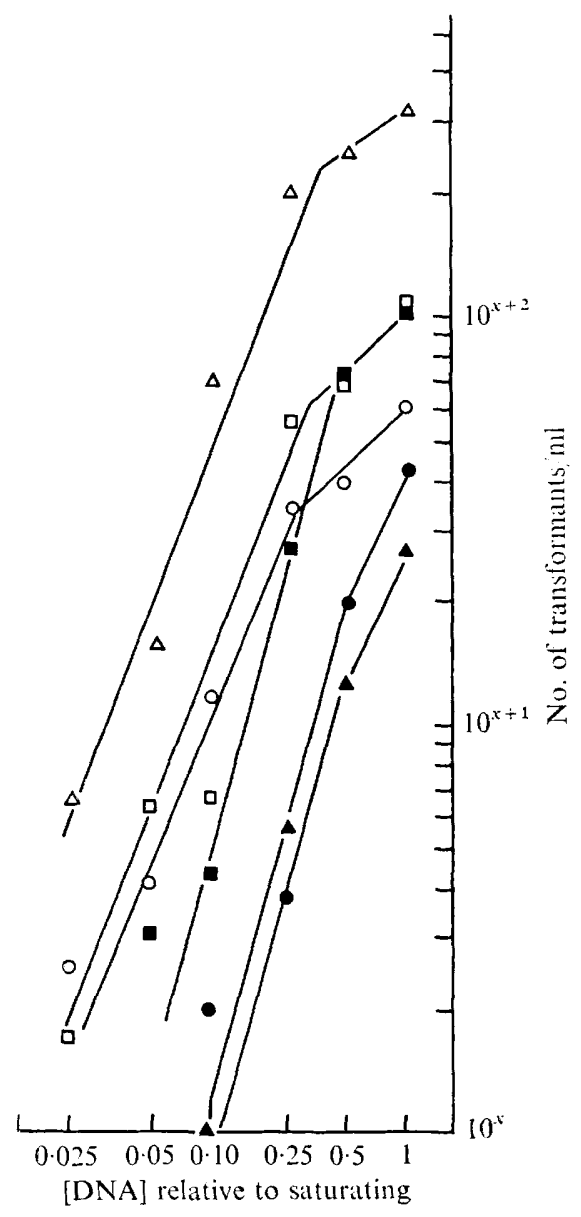

Fig. I. Dilution curves for transformants to the markers str-r4I $(0, x=5)$, ery-r2 $(\Delta, x=4)$, opt-r2 $(\square, x=4)$, str-r4I ery-r2 $(\mathbf{O}, x=3)$, str-r4I opt-r2 $(\boldsymbol{\Lambda}, x=3)$ and ery-rz opt-r2 $(\square, x=2)$ resulting from the cross $\mathrm{cl}_{3} \times\left(\mathrm{r}_{2} \mathrm{SQ}\right)$.

Table 3. Double transformants not involving the tet-A marker: values of the linkage index (l.i.) and co-transfer index $(\mathrm{CoI})$ of double transformants resulting from mixtures of singly marked $D N A$

\begin{tabular}{|c|c|c|c|c|c|c|}
\hline \multirow{2}{*}{$\begin{array}{l}\text { Relative } \\
\text { [DNA] }\end{array}$} & \multicolumn{2}{|c|}{$\begin{array}{c}\mathrm{Cl} 3 \times\left(\mathrm{Cl}_{3}-\mathrm{s}\right)\left(\mathrm{Cl}_{3}-\mathrm{r}_{2}\right) \\
\text { str-r4 } 4 \text { e ery-r2 }\end{array}$} & \multicolumn{2}{|c|}{$\begin{array}{c}\mathrm{cl}_{3} \times\left(\mathrm{Cl}_{3}-\mathrm{s}\right)\left(\mathrm{Cl}_{3}-\mathrm{Q}\right) \\
\text { str-r4I opt-r2 }\end{array}$} & \multicolumn{2}{|c|}{$\begin{array}{l}\mathrm{cl} 3 \times(\mathrm{Aml})\left(\mathrm{r}_{2} \mathrm{SQ}\right) \\
\text { amiA }-r I \text { str-r } 4 I\end{array}$} \\
\hline & 1.i. & CoI & 1.i. & $\mathrm{CoI}$ & 1.i. & $\mathrm{CoI}$ \\
\hline Saturating & $1 \cdot 9$ & 0.0066 & $4 \cdot 0$ & 0.0015 & - & 一 \\
\hline 0.5 Sat. & $\mathrm{I} \cdot 8$ & 0.0058 & $3 \cdot 8$ & 0.0009 & - & - \\
\hline 0.25 Sat. & - & - & - & - & $4 \cdot 5$ & 0.0020 \\
\hline o. Is Sat. & $2 \cdot 5$ & 0.0039 & $5 \cdot 9$ & 0.0003 & - & - \\
\hline 0.075 Sat. & $2 \cdot 3$ & 0.0032 & $4 \cdot 5$ & 0.0002 & - & - \\
\hline 0.038 Sat. & $3 \cdot 2$ & 0.0015 & $3 \cdot 3$ & 0.00004 & - & 一 \\
\hline 0.015 Sat. & $2 \cdot 7$ & 0.0010 & - & - & - & - \\
\hline 0.0075 Sat. & $3 \cdot 2$ & 0.0005 & - & - & - & - \\
\hline Average & $2 \cdot 5$ & 0.0032 & $4 \cdot 3$ & 0.0007 & $4 \cdot 5$ & 0.0020 \\
\hline
\end{tabular}


Table 4. Double transformants involving the tet-A marker: values of the linkage index (l.i.) and co-transfer index $(\mathrm{CoI})$ of the double transformants using multiply marked DNA

\begin{tabular}{|c|c|c|c|c|c|c|c|c|}
\hline \multirow{2}{*}{$\begin{array}{l}\text { Relative } \\
\text { [DNA] }\end{array}$} & \multicolumn{2}{|c|}{$\begin{array}{c}\text { tet }-A \text { str-r } 4 \mathrm{I} \\
\mathrm{cl}_{3} \times\left(\mathrm{Tc}_{3} \mathrm{Amlr}_{2} \mathrm{SQ}\right)\end{array}$} & \multicolumn{2}{|c|}{$\begin{array}{c}\text { tet }-A \text { ami } A-r I \\
\mathrm{cl} 3 \times\left(\mathrm{Tc}_{3} \mathrm{Amlr}_{2} \mathrm{SQ}\right)\end{array}$} & \multicolumn{2}{|c|}{$\begin{array}{c}\text { tet }-A \text { ery-r2 } \\
\mathrm{cl}_{3} \times\left(\mathrm{Tc}_{3} \mathrm{Amlr}_{2} \mathrm{SQ}\right)\end{array}$} & \multicolumn{2}{|c|}{$\begin{array}{c}\text { tet }- \text { A opt-r } 2 \\
\mathrm{cl}_{3} \times\left(\mathrm{Tc}_{3} \mathrm{r}_{2} \mathrm{SQ}\right)\end{array}$} \\
\hline & 1.i. & $\mathrm{CoI}$ & l.i. & $\mathrm{CoI}$ & 1.i. & $\mathrm{CoI}$ & l.i. & $\mathrm{CoI}$ \\
\hline I.o Sat. & $I \cdot 2$ & 0.022 & $2 \cdot 4$ & 0.0020 & 0.024 & 0.437 & 0.90 & 0.012 \\
\hline 0.5 Sat. & $I \cdot 2$ & 0.016 & $5 \cdot 9$ & 0.0007 & $0.03 \mathrm{I}$ & 0.388 & 0.90 & 0.010 \\
\hline 0.I4 Sat. & $\mathrm{I} \cdot 2$ & 0.013 & $2 \cdot 3$ & 0.0020 & 0.019 & $0.2 \mathrm{I} 2$ & $\mathrm{I} \cdot 8$ & 0.004 \\
\hline 0.07 Sat. & $\mathrm{I} \cdot 7$ & 0.007 & $5 \cdot 4$ & 0.0007 & 0.016 & 0.162 & $1 \cdot 7$ & 0.003 \\
\hline 0.035 Sat. & $\mathrm{I} \cdot 6$ & 0.005 & I I $\cdot 7$ & 0.0003 & 0.0095 & 0.161 & $\mathrm{I} \cdot 7$ & 0.002 \\
\hline o.0I4 Sat. & - & 一 & - & - & O.OII & 0.088 & $I \cdot 2$ & 0.002 \\
\hline \multirow[t]{2}{*}{0.007 Sat. } & - & - & - & - & 0.0065 & 0.105 & 0.8 & 0.002 \\
\hline & & & \multicolumn{6}{|c|}{$\mathrm{Cl}_{3} \times\left(\mathrm{Tc}_{3} \mathrm{r}_{2} \mathrm{Q}\right)$} \\
\hline I.O Sat. & - & - & - & 一 & 0.016 & 0.170 & 一 & - \\
\hline 0.29 Sat. & - & - & - & - & 0.012 & 0.142 & - & - \\
\hline o. I5 Sat. & 一 & - & - & - & 0.010 & 0.114 & 一 & - \\
\hline $0.075 \mathrm{Sat}$. & - & - & - & - & 0.0058 & 0.126 & 一 & 一 \\
\hline 0.029 Sat. & - & - & - & - & 0.0037 & 0.132 & - & $\ldots$ \\
\hline 0.015 Sat. & - & 一 & - & - & 0.0026 & 0.099 & - & - \\
\hline 0.0075 Sat. & - & - & - & - & $0 \cdot 0016$ & 0.090 & - & - \\
\hline
\end{tabular}

points for the lower dilution being well below the abcissa. A control dilution curve was carried out using a mixture of two DNA preparations, one containing the tet- $A$ marker and the other the ery-rz marker. In this case, co-transfer was impossible and double transformants must be resultants of double events. The curves obtained are shown in Fig. 3 and the numbers of tet-A ery-r2 transformants fell off rapidly with decreasing DNA concentration.

DNA prepared by method II. DNA was prepared from strain $\mathrm{Tc}_{3} \mathrm{r}_{2} \mathrm{~s}$ by method II and dilution curves carried out for single transformants and for the three possible pairs of double transformants. The curves obtained are shown in Fig. 4 and the values of the linkage index of the double transformants are recorded in Table 5. Again, evidence of linkage was obtained for the tet-A and ery-r2 markers, but no linkage was found for the tet- $A$ and str-r $4 I$ markers, nor for the ery-r 2 and str-r $4 I$ markers. It is of interest to note that the tet- $A$ str-r $4 I$ system gave higher linkage indices than the ery-r2 str-r4I system although tet- $A$ and ery-r2 are themselves closely linked. The reason for this is unknown, but perhaps it is due to an interference mechanism.

Clonal analysis. Strain $\mathrm{Cl}_{3}$ was treated with DNA prepared from strain $\mathrm{Tc}_{3} \mathrm{r}_{2} \mathrm{SQ}$ and scored for single transformants for the ery-r2, tet-A and str-r $4 I$ markers, and also for the double transformants tet-A ery-r2, tet-A str-r4I and ery-r2 str-r4I. At the same time a c.f.u. count was done on the recipient culture. The frequencies of each transformant type were calculated and those for the doubles compared with the calculated maximum frequencies for double events. Then I Io colonies of each transformant type were analysed for the presence of all these markers, and the results are summarized in Fig. 5. The total number of transformants and the frequency of each transformant type are given, with the calculated frequencies for the double transformants in square brackets. The analysis of the transformant types is given as the number of colonies having the indicated genotype. Of the single transformants to ery-r2, a high proportion was also resistant to tetracycline; similarly, the tet- $A$ transformants exhibited a very strong tendency to be also erythromycin-resistant. These results must be interpreted as showing linkage between ery-rz and tet-A. Both the tet-A 


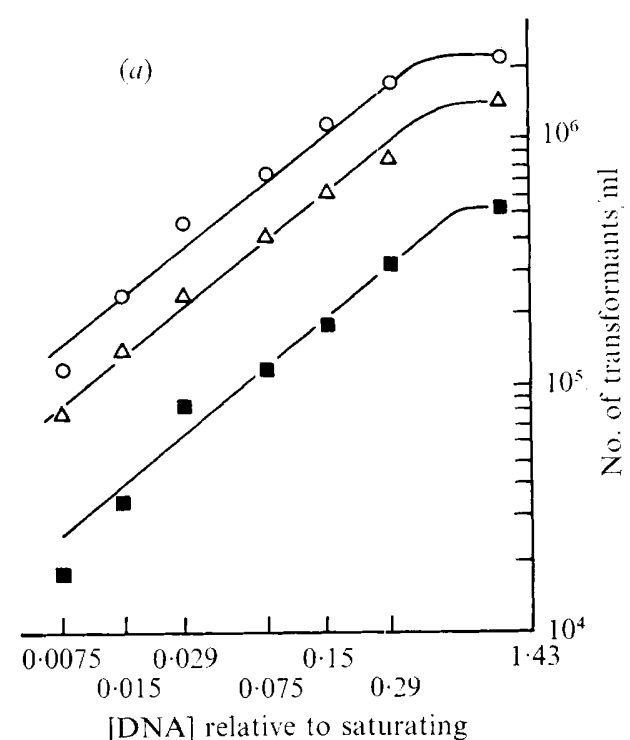

[DNA] relative to saturating

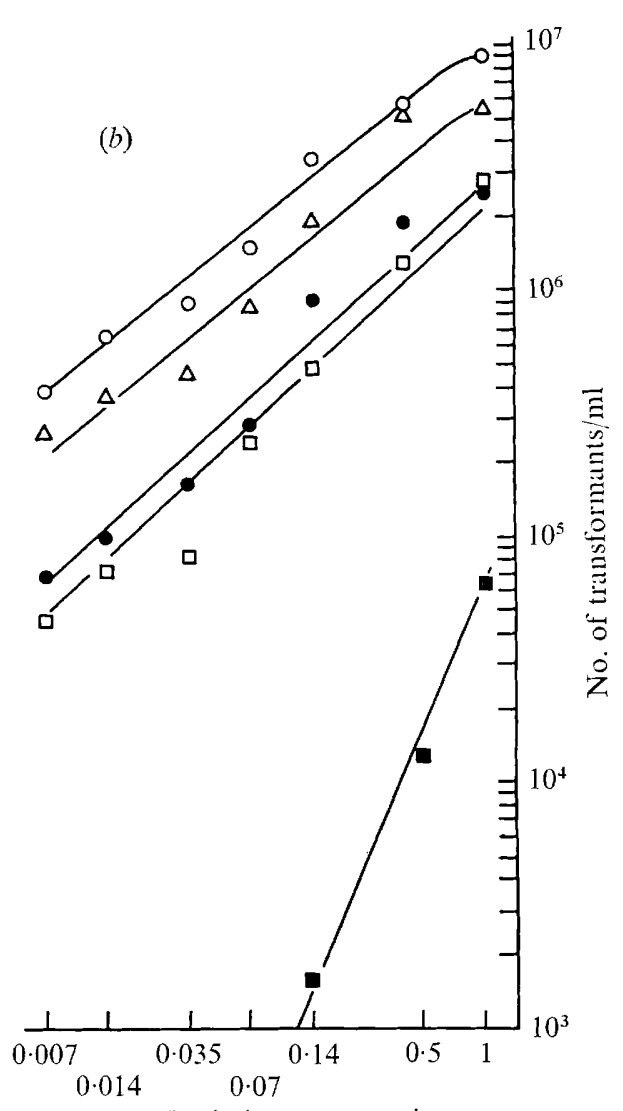

[DNA] relative to saturating

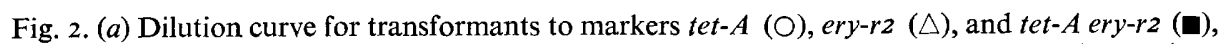
resulting from the cross $\mathrm{cl}_{3} \times\left(\mathrm{Tc}_{3} \mathrm{r}_{2} \mathrm{Q}\right)$. (b) Dilution curve for the transformants to the markers

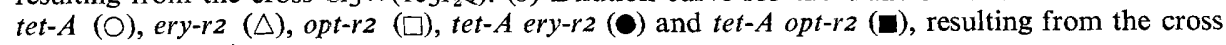
$\mathrm{Cl}_{3} \times\left(\mathrm{Tc}_{3} \mathrm{AmI} \mathrm{r}_{2} \mathrm{SQ}\right)$.

$s t r-r 4 I$ and the ery-r2 str-r4I double transformants had relatively high proportions of tet- $A$ ery-r2 str-r4I triple transformants, the third marker being brought in by its linkage to the tet- $A$ gene in the former and the ery-r2 gene in the latter case. There was little evidence to support linkage between ery-r2 and str-r $4 I$ and, taken with the previous results, it must be concluded that there is no such linkage.

Although the DNA concentration used in the transformation was just below saturating, it was still high enough to give str transformants at a frequency of $\mathrm{I}$ in 27 (i.e. I in 13.5 with reference to the uncorrected c.f.u. count). This frequency of transformation is still high enough to be able to give a number of double transformants to unlinked markers resulting from two events. This would account for the three ery str double transformants out of the I I o selected ery colonies; it may also help to explain the I 2 colonies containing str as a third marker together with the tet ery amongst the I Io selected tet-ery double transformants, although we feel that some other factor inherent in the selection of the colonies analysed may contribute to this figure. The values of the linkage index and co-transfer index strongly indicate that this factor is not linkage. 


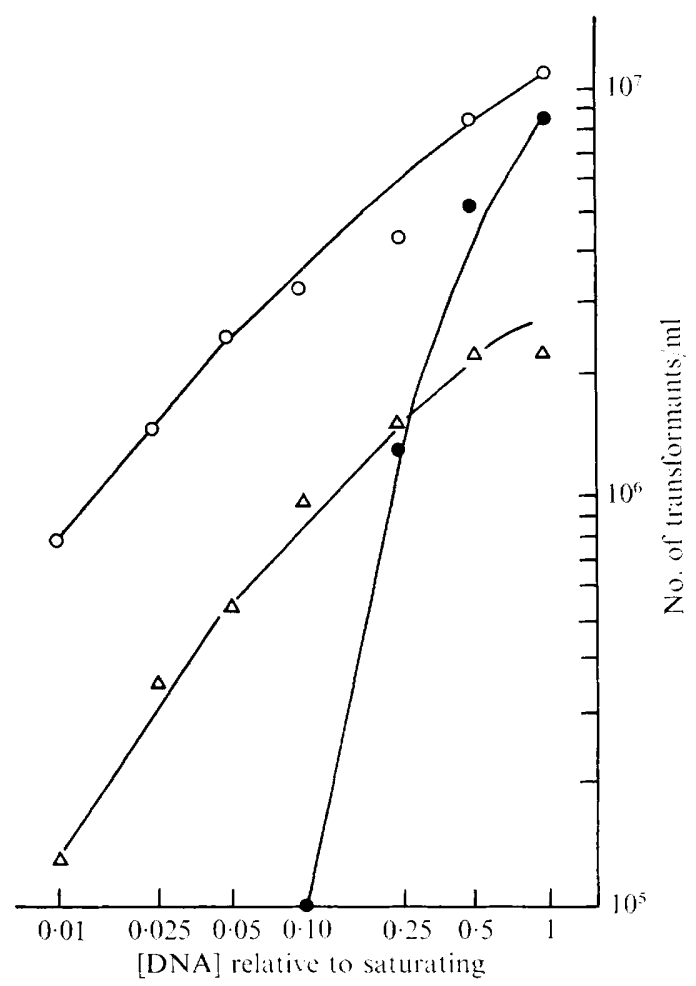

Fig. 3. Dilution curves for the transformants to the markers tet-A (O), ery-r2 $(\triangle)$, and tet-A ery-r2 (O), resulting from the cross $\mathrm{Cl}_{3} \times\left(\mathrm{Cl}_{3}-\mathrm{Tc}_{3}\right)\left(\mathrm{Cl}_{3}-\mathrm{r} 2\right)$, i.e. using a mixture of two preparations of DNA, one containing the tet- $A$ marker and the other the ery-r 2 marker.

Table 5. Values of the linkage index (li.) and co-transfer index (CoI) for double transformants involving the tet-A marker, using multiply marked donor DNA prepared by method II

\begin{tabular}{|c|c|c|c|c|c|c|}
\hline \multirow[b]{3}{*}{ Relative [DNA] } & \multicolumn{6}{|c|}{$\mathrm{Cl}_{3} \times\left(\mathrm{Tc}_{3} \mathrm{r}_{2} \mathrm{~s}\right) \mathrm{II}$} \\
\hline & \multicolumn{2}{|c|}{ tet $-A$ ery-rz } & \multicolumn{2}{|c|}{ tet-Astr-r4I } & \multicolumn{2}{|c|}{$e r y-r 2$ str-r4I } \\
\hline & 1.i. & $\mathrm{CoI}$ & l.i. & $\mathrm{CoI}$ & l.i. & CoI \\
\hline Saturating & 0.089 & 0.208 & $6 \cdot 8$ & 0.0039 & $I \cdot 9$ & 0.011 \\
\hline 0.5 Sat. & 0.068 & $0 \cdot 154$ & $8 \cdot 9$ & 0.0024 & $2 \cdot 2$ & $0.007 \mathrm{I}$ \\
\hline 0.25 Sat. & 0.086 & 0.169 & $15 \cdot 0$ & $0.001 \mathrm{I}$ & $2 \cdot 8$ & 0.0046 \\
\hline 0.10 Sat. & $0.05 \mathrm{I}$ & 0.154 & $18 \cdot 5$ & 0.0006 & $2 \cdot 5$ & 0.0029 \\
\hline 0.05 Sat. & 0.025 & 0.236 & $7 \cdot 2$ & 0.0010 & $3 \cdot 4$ & 0.0017 \\
\hline 0.025 Sat. & 0.014 & 0.175 & $23 \cdot 0$ & 0.0001 & $I \cdot 9$ & 0.0012 \\
\hline 0.0 I Sat. & 0.0033 & 0.195 & - & - & $I \cdot 2$ & 0.0007 \\
\hline Average & 0.048 & 0.184 & $13 \cdot 2$ & 0.0015 & $2 \cdot 3$ & 0.0042 \\
\hline
\end{tabular}

\section{DISCUSSION}

Comparisons of results obtained for crosses with multiply marked DNA with those obtained with mixtures of singly marked DNA showed that both the linkage index and the co-transfer index were of the same order for doubles involving the str r4I, opt-r2, amiA-rI and ery-r2 markers. Since these markers could not be linked in the experiment involving mixtures of DNA when the markers were on different preparations, it follows that they 


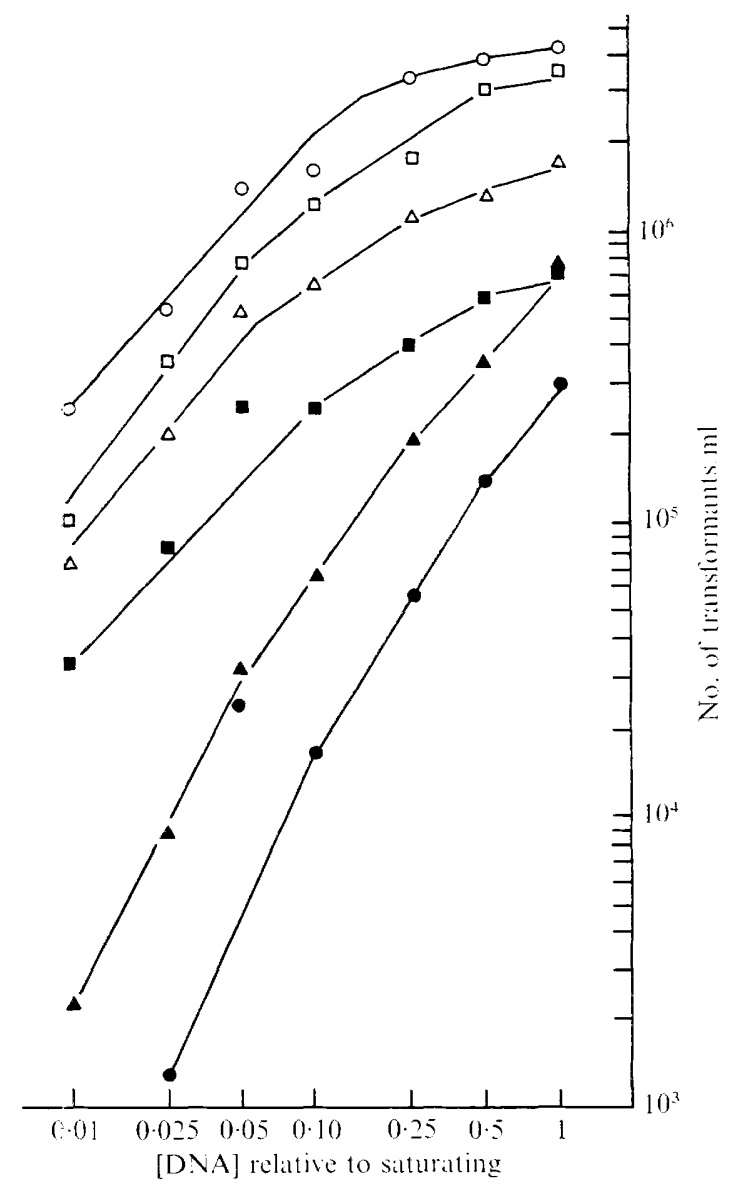

Fig. 4. Dilution curves for transformants to the markers str-r4I (O), tet-A $(\square)$, ery-r2 $(\triangle)$, tet-A

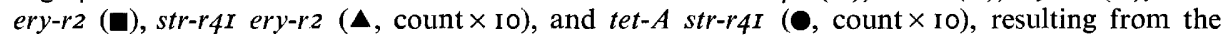
cross $\mathrm{Cl}_{3} \times\left(\mathrm{Tc}_{3} \mathrm{r}_{2} \mathrm{~s}\right)_{\Pi}$.

were not linked with crosses involving multiply marked DNA. Hence the results confirm the lack of linkage between the str-r4I, opt-r2, amiA-rI and ery-r2 markers inferred by Rolfe \& Ephrussi-Taylor (I96I), Martin \& Ephrussi-Taylor (I964) and Louarn \& Sicard (1969). The similarities in the values of the indices were most marked with the ery-r2 str-r4I double. However, Ravin (I966) and Ravin \& Chen (I967) reported a weak linkage between ery-r2 and str-r 53. The str-r 53 marker is situated in the same locus as str-r $4 I$ and may cover the latter marker. The discrepancy between the results presented here and those of Ravin may be due either to different methods of DNA preparation or to the use of different recipient strains. Ravin used a method of preparation similar to method I involving the Sevag technique of deproteinization. This may, in fact, produce conditions leading to breakage of the DNA. Method II, however, was physically much more gentle and produced a product having long strands on spooling. The results obtained with this preparation still gave cotransfer of ery-r2 and tet $-A$, but there was again no evidence of linkage of ery-r2 with str-r4I. It would seem more probable that the differences are due to the two recipient strains. The strain used by the Ravin laboratory was strain sIII-I derived by Ephrussi-Taylor (I95I), by transformation of R36A with A66IIIN-DNA which was followed by at least one mutational 


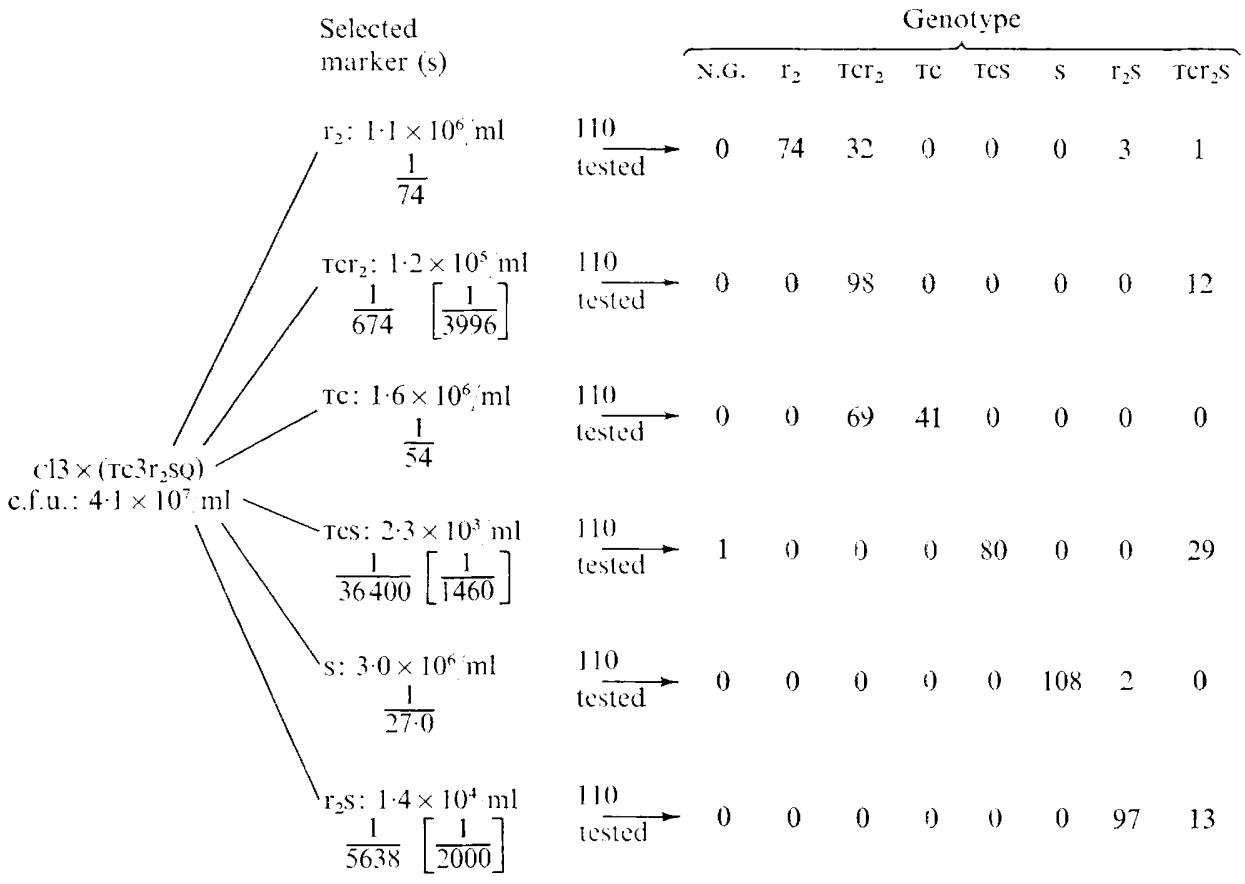

Fig. 5. Clonal analysis of the cross $\mathrm{Cl} 3 \times\left(\mathrm{Tc}_{3} \mathrm{r}_{2} \mathrm{SQ}\right)$. Experimental frequencies of the selected transformants are given, with the calculated frequencies for the double transformants in brackets; 1 Io colonies of each of a single and double transformant type were analysed and the number having the indicated genotype recorded. $\mathrm{r}_{2}=e r y-r_{2} ; \mathrm{TC}=t e t-A ; \mathrm{s}=s t r-r 4 I ;$ N.G. $=$ no growth.

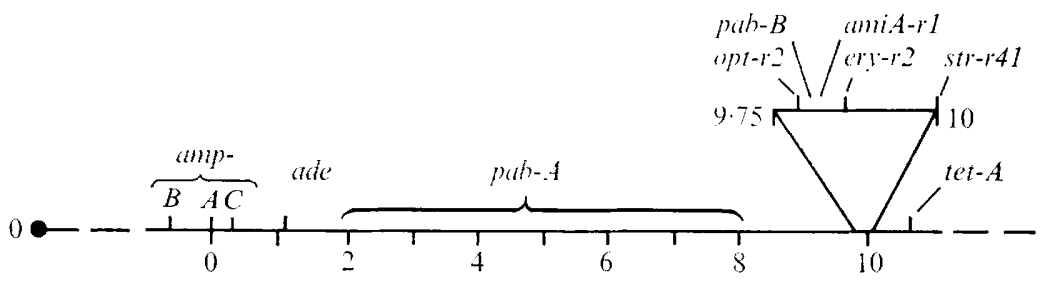

Fig. 6. Map of the pneumococcal chromosome derived from density-shift experiments (Butler \& Smiley, 1973). The distance between the amp-ArI marker and the str-r4I marker was taken as equal to 10.00 units, and the relative positions of the other markers calculated.

event. It therefore has a different history than the strain $\mathrm{Cl}_{3}$ used as recipient in this laboratory. Further work has shown that there is indeed a difference in the linkage behaviour when strain SIII- $\mathrm{I}$ is used as recipient compared to strain $\mathrm{Cl}_{3}$, and a preliminary report of these findings has been published (Butler, 1973).

The results described show that there is co-transfer of ery-r2 and tet-A. A previous paper (Butler \& Smiley, 1973) described the relative positions of the markers obtained by the density-shift method and the map obtained is reproduced in Fig. 6. It will be seen that the replication order of the markers in this region of the chromosome is -ery-r2-str-r4I-tet-A-, so that str-r4I is situated between ery-r2 and tet-A. Since ery-r2 and tet-A show linkage, the map would indicate that str-r $4 I$ should also be linked to both ery-r 2 and to tet-A. This, however, is not the case, and hence there is a discrepancy between the linkage data and the 


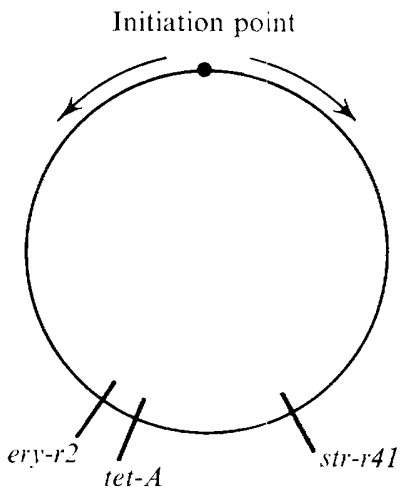

(a)

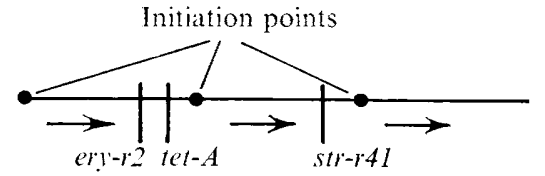

(b)

Fig. 7. Models proposed for the replication of the pneumococcal chromosome. (a) A model having one initiation point but bi-directional replication giving two replicating units; $(b)$ a model having several initiation points with uni-directional replication in several replicating units.

map obtained by density shift. The density-shift method gives the order of replication of the markers, and this would be identical to the linear order of the markers on the chromosome only if the chromosome was composed of one replicon having one initiation point from which the replicating point travelled along the chromosome in one direction. It is possible, however, that more than one replicating unit may exist in the pneumococcal chromosome, and two models, depicted in Fig. 7, can be proposed, which would explain the discrepancies. In Fig. 7(a) a circular chromosome has been divided into two such units by having one initiation point from which replication proceeds in both directions around the chromosome. In this way, ery-r2 and tet- $A$ would be situated towards the end of one unit and str-r4I would be situated towards the end of the other unit at such a distance from the initiation point that it would be replicated between ery-r2 and tet-A. Evidence suggesting the presence of two replicating units has been put forward by Caro \& Berg $(1968,1969)$ for the $\mathrm{F}^{+}$and $\mathrm{F}^{-}$strains of Escherichia coli, by Masters \& Broda (I97I) also for E. coli and by Nishioka \& Eisenstark (1970) for Salmonella typhimurium, all using transduction techniques, and by Yahara (I97I) and Bird, Louarn, Martuscelli \& Caro (1972) using DNA-DNA hybridization techniques. Evidence has also been presented in favour of bi-directional replication in Bacillus subtilis (Wake, 1972).

In Fig. $7(b)$ the chromosome, depicted for simplicity as a straight line, has been divided into several replicating units, each having its own initiation point with uni-directional replication. It could be postulated that initiation of each unit occurs simultaneously, that the units are of similar sizes and that the DNA synthesis in each unit occurred at similar rates. In this way, ery-r2 and tet- $A$ would occur towards the end of one unit whilst str-r $4 I$ would occur towards the end of another unit. An extension of this model would allow for bi-directional replication from each of the initiation sites. Evidence of such a mechanism has been put forward in the study of the replication of mammalian chromosomes by Huberman \& Riggs (I968) and by Callan (1972).

It seems that the model in Pneumococcus shown in Fig. $7(a)$ is more likely, in view of the evidence quoted above obtained by various independent groups of workers using different techniques. However, little is known concerning the replication of the pneumococcal chromosome, and the results reported above could be taken to support a multi-replicating 
unit system. More light will be thrown on the problem as more mapping is achieved and more linkage groups are found.

Thanks are due for the technical assistance given by Mlle C. Genin, Fraulein M. Kobel and Fraulein A. M. Günther, and to the Medical Research Council for financial assistance for a part of this work. My thanks are also due to Professor A. M. Sicard for many useful and stimulating discussions during the course of the work, and for reading the manuscript.

\section{REFERENCES}

Anagnostopoulos, C. \& Crawford, I. P. (I96I). Transformation studies on the linkage of markers in the tryptophan pathway in Bacillus subtilis. Proceedings of the National Academy of Sciences of the United States of America 47, 378-390.

Avery, O. T., MacLeod, C. M. \& MCCarTy, M. (1944). Studies on the chemical nature of the substance inducing pneumococcal types. Induction of transformation by a deoxyribonucleic acid fraction isolated from Pneumococcus type III. Journal of Experimental Biology, 89, I37-157.

Bacon, M. F., Overend, W. G., Lloyd, P. H. \& Peacocke, A. R. (I967). The isolation, comparison and physicochemical properties of deoxyribonucleic acid from Bordetella pertussis. Archives of Biochemistry and Biophysics I18, 352-36I.

Bird, R. E., LouARn, J., MARTusCelli, J. \& CARo, L. (1972). Origin and sequence of chromosome replication in Escherichia coli. Journal of Molecular Biology 70, 549-566.

Berns, K. I. \& Thomas, C. A. (1965). Isolation of high molecular weight DNA from Haemophilus influenzae. Journal of Molecular Biology II, 476-490.

BUtLeR, L. O. (1965). A co-precipitation method for the preparation of transforming DNA from small samples of low density bacterial cultures. Journal of General Microbiology 39, 247-252.

ButLer, L. O. (1973). Bacterial Transformation, pp. 35I-367. Edited by L. J. Archer. London: Academic Press.

Butler, L. O. \& Smiley, M. B. (I970). Characterization by transformation of an ampicillin-resistant mutant of pneumococcus. Journal of General Microbiology 6r, 189-195.

Butler, L. O. \& SmiLey, M. B. (1973). Mapping of the pneumococcus chromosome: application of the density-shift method. Journal of General Microbiology 76, ro I-I I 3.

CAHN, F. H. \& Fox, M.S. (I968). Fractionation of transformable bacteria from competent cultures of Bacillus subtilis on renograffin gradients. Journal of Bacteriology 95, 867-875.

Callan, H. G. (1972). Replication of DNA in the chromosomes of eukaryotes. Proceedings of the Royal Society B I8I, I9-4I.

CARo, L. G. \& Berg, C.M. (1968). Chromosome replication in some strains of Escherichia coli KI2. Cold Spring Harbor Symposia on Quantitative Biology 33, 559-573.

CARo, L. G. \& Berg, C. M. (1969). Chromosome replication in Escherichia coli. II. Origin of replication in $\mathrm{F}^{-}$and $\mathrm{F}^{+}$strains. Journal of Molecular Biology 45, 325-336.

Ephrussi-TAYLOR, H. (195I). Transformations allogènes du pneumocoque. Experimental cell Research 2, 589-607.

Fox, M. S. \& Hoтchкiss, R. D. (1957). Initiation of bacterial transformation. Nature, London 179, I3221325 .

Hotchkiss, R. D. \& MARmuR, J. (1954). Double marker transformations as evidence of linked factors in deoxyribonucleate transforming agents. Proceedings of the National Academy of Sciences of the United States of America $40,55$.

Huberman, J. A. \& Riggs, A. D. (1968). On the mechanism of DNA replication in mammalian chromosomes. Journal of Molecular Biology 32, 327-34I.

KIRBY, K. S. (1965). Isolation and characterization of ribosomal ribonucleic acid. Biochemical Journal 96, 266-269.

LouARn, J.-M. \& SiCARD, A. M. (1969). Identical transformability of both strands of recipient DNA in Diplococcus pneumoniae. Biochemical and Biophysical Research Communications 36, IOI-109.

MARTIN, C. \& EPHRUSSI-TAYLOR, H. (1964). Effects of partial deuteration on transforming DNA of pneumococcus. Biochimica et biophysica acta 80, $4 \mathrm{I} \mathrm{I}-42 \mathrm{I}$.

MASTERS, M. \& BRODA, P. (197I). Evidence for the bi-directional replication of the Escherichia coli chromosome. Nature New Biology 232, 137-I40. 
Nester, E. W. \& LEDERBERG, J. (1961). Linkage of genetic units of Bacillus subtilis in DNA transformation. Proceedings of the National Academy of Sciences of the United States of America 47, 52-55.

Nester, E. W. \& Stocker, B. A. D. (1963). Biosynthetic latency in early stages of deoxyribonucleic acid transformation in Bacillus subtilis. Journal of Bacteriology 86, 785-796.

NishIOKA, Y. \& EISENSTARK, A. (1970). Sequence of genes replicated in Salmonella typhimurium as examined by transduction techniques. Journal of Bacteriology 102, 320-333.

PorTer, R. D. \& Guild, W. R. (1969). Number of transformable units per cell in Diplococcus pneumoniae. Journal of Bacteriology 97, 1033-I035.

Ravin, A.W. (1966). Intergenic and intragenic recombination during DNA-induced transformation. Symposium on the Mutational Process. The Physiology of Gene and Mutation Expression. Czechoslovak Academy of Science, p. 139.

RAvin, A. W. \& ChEN, K. C. (1967). Heterospecific transformation of pneumococcus and streptococcus. III. Reduction of linkage. Genetics 57, 85I-864.

RolfE, R. \& EPHRUSSI-TAYLOR, H. (196I). Density differences between genetic markers in pneumococcal transforming principle. Proceedings of the National Academy of Sciences of the United States of America 47, I450-I $46 \mathrm{I}$.

SevaG, M. G., Lackman, D. B. \& Smolens, J. (1938). The isolation of the components of streptococcal nucleoproteins in serologically active form. Journal of Biological Chemistry 124, 425-436.

SiCARD, A. M. (1964). A new synthetic medium for Diplococcus pneumoniae and its use for the study of reciprocal transformation at the amiA locus. Genetics 50, 3I-44.

SicARD, A. M. (1965). Analyse génétique de la structure fine du locus amiA chez Diplococcus pneumoniae. Thèse ès Sciences, Université de Paris.

WAKE, R. G. (1972). Visualization of reinitiated chromosomes in Bacillus subtilis. Journal of Molecular Biology 68, 501-509.

YAHARA, Y. (1971). On the replication of Escherichia coli chromosome. Journal of Molecular Biology 57, $373-376$. 